(Revised)

\title{
Organizing the Innovation Process: Complementarities in Innovation Networking
}

\author{
James H Love ${ }^{1}$ and Stephen Roper ${ }^{2}$ \\ ${ }^{1}$ Economics and Strategy Group, Aston Business School, Aston University, \\ Birmingham B4 7ET, UK \\ Email: j.h.love@aston.ac.uk
}
${ }^{2}$ Centre for Small and Medium-Sized Enterprises, Warwick Business School, University of Warwick, Coventry, CV4 7AL, UK. Email: stephen.roper@wbs.ac.uk

\begin{abstract}
This paper contributes to the developing literature on complementarities in organizational design. We test for the existence of complementarities in the use of external networking between stages of the innovation process in a sample of UK and German manufacturing plants. Our evidence suggests some differences between the UK and Germany in terms of the optimal combination of innovation activities in which to implement external networking. Broadly, there is more evidence of complementarities in the case of Germany, with the exception of the product engineering stage. By contrast, the UK exhibits generally strong evidence of substitutability in external networking in different stages, except between the identification of new products and product design and development stages. These findings suggest that previous studies indicating strong complementarity between internal and external knowledge sources have provided only part of the picture of the strategic dilemmas facing firms.
\end{abstract}

Keywords: Innovation; networking; complementarities; UK; Germany

\section{Acknowledgements:}

The research reported in this paper was supported by the ESRC under award RES-000-220813. This paper was written while Jim Love was an academic visitor at CIBAM, Judge Business School, University of Cambridge and Visiting Fellow of Wolfson College, Cambridge. We are grateful for the research assistance provided by Giovanni Mangiarotti and for the constructive comments of two anonymous referees. 


\section{Introduction}

Effective innovation depends crucially on firms' ability to absorb external knowledge, combine it with their own proprietorial knowledge and develop new market offerings (Chesbrough, 2003; Roper et al., 2008). The strategic challenge is how firms can best organize the sourcing, codification and exploitation of the internal and external knowledge and informational resources to maximise and sustain innovation (e.g. Zahra and George, 2002; Davila et al., 2005). An important element in this process is the identification and effective harnessing of knowledge complementarities between different activities inside and outside the boundaries of the firm, so optimising resource use (e.g. Milgrom and Roberts, 1990, 1995) ${ }^{1}$. For example, in terms of optimising knowledge sourcing, firms face the classic 'make' or 'buy' trade-off or, more realistically perhaps, face a choice between conducting in-house R\&D, external R\&D, or both (Veugelers and Cassiman, 1999; Love and Roper, 2001, 2002; Cassiman and Veugelers, 2006). Cassiman and Veugelers (2006) also suggest that complementarities may arise between in-house and external R\&D due to firms' improved scanning ability for external knowledge sources, the ability to exchange internally generated for externally sourced knowledge, enhanced absorptive capacity, or increased appropriation capacity. In their own empirical analysis, Cassiman and Veugelers (2006) find positive evidence of complementary effects on innovation performance from combining make and buy strategies (see also Griffiths et al., 2003).

Our paper offers two innovations with regard to the existing literature on complementarity in knowledge sourcing. First, unlike previous studies we recognize that innovation is a process rather than an event, and comprises a number of different activities, running from the identification and prototyping of new products through their development and production to the implementation of marketing strategy. We are able to consider, both separately and in combination, the use of internal and external knowledge in four discrete stages of new product development: identifying new products, product design and development, product engineering, and product marketing. We argue - as indeed turns out to be the case - that there is no guarantee that the same mix of internal and external knowledge will be optimal in all stages of the innovation process. In this paper we therefore

\footnotetext{
${ }^{1}$ Cassiman and Veugelers (2006), and others, have drawn a parallel between the search for strategic complementarities and notions of strategic 'fit' in the strategic management literature (e.g. Porter, 1996).
} 
consider a slightly different but related question to previous research, focusing on whether there is complementarity between innovation networking in different stages of the innovation process. For example, does accessing external knowledge as part of firms' product design activity contribute more to innovation outputs if the firm is also engaging in networking in other stages of its innovation activity?

The second innovation is to consider such complementarities in a comparative framework, looking at how complementarities in innovation networking are shaped by differences in UK and German firms' operating environments and internal capabilities. The UK-Germany comparison is of particular interest both because of shortcomings in UK national innovation performance, differences in the nature of innovation activity (Finegold and Wagner, 1998; Herrigel, 1996), and the marked institutional and organizational contrasts between the two countries (Finegold and Soskice, 1988; Dore et al., 1999; Culpepper, 1999; Love and Roper 2004).

Our empirical approach makes use of the concepts of supermodularity and complementarity in organizational design developed by Milgrom and Roberts (1990, 1995). This builds on the work of Topkis (1978), and was first operationalised in the context of innovation policy by Mohnen and Röller (2005). Two activities are (Edgeworth) complementary if doing more of one activity increases the returns from doing the other. This is a precise, technical definition in which complementarity exists only when these beneficial marginal effects are realized $^{2}$. This approach is appropriate in the present case because we wish to examine the use of internal and external knowledge in each of the four stages of new product development, but also in combination. Thus we cannot merely consider the complementarity between internal and external knowledge in each individual stage, because of the potential for complementarities in the use of internal and external knowledge between stages. The supermodularity approach is well suited to analysis of this type.

The next section summarises the literature on knowledge sourcing and innovation, and explains the institutional differences between UK and German manufacturing plants in terms of their use of external networking and innovation. Section 3 describes our data and

\footnotetext{
${ }^{2}$ Contrast this with the approach of e.g. Harrison et al (2001) who argue that the existence of complementary resources is a necessary but insufficient condition to achieve synergy.
} 
details the empirical method used to test for complementarities, with empirical results in section 4. Conclusions and implications are presented in section 5.

\section{Knowledge Sourcing and Innovation}

Achieving the optimal mix between internal knowledge generation and external knowledge sourcing for innovation suggests a strategic choice similar to that relating to outsourcing in the core competencies literature. Economics offers a range of perspectives on this type of strategic decision. In terms of the transactions cost literature, for example, the firm's minimand is cost, although issues of appropriability, contract compliance and the potential for hold-up need also to be considered (e.g. Love and Roper, 2002). A resource-based view, however, focuses more directly on the strategic priorities of the firm and the desire to develop 'core' and out-source 'non-core' competencies (Prencipe, 1997; Takeishi 2001). In both perspectives, however, a substitute relationship is implicitly assumed between those activities conducted within the firm and those out-sourced. However, there are no strong $a$ priori grounds for expecting a substitute rather than a complementary relationship between internal and external knowledge resources in innovation. The use of external $R \& D$, for example, may have advantages for firms in overcoming the limitations of in-house R\&D budgets, or in gaining access to the economies of scale and scope available to specialist research organizations. External R\&D links may also be a useful method of searching the technological environment in a systematic fashion, permitting access to improved technology developed elsewhere (Mowery, 1990; Niosi, 1999). Using external knowledge, however, also has potential disadvantages. Difficulties assigning intellectual property rights may make external R\&D unattractive, as may the lack of appropriate expertise of potential contractors compared to those within a firm's own R\&D department. Conversely, under conditions of asymmetric information which will often prevail in the context of research and innovation, a combination of uncertainty and principal-agent type arguments may make external R\&D seem more attractive, but can lead to problems of monitoring as the agent is able to exaggerate the costs and commercial potential of their innovations (Audretsch et al, 1996; Ulset, 1996).

Increasingly, therefore, the theoretical and empirical literature is emphasizing the possibility that the relationship between internal and external knowledge sourcing for innovation is not 'either/or', but one which may involve significant complementarities between these two 
sources. For example, the absorptive capacity role of internal R\&D is now widely recognized (Cohen and Levinthal 1989; Zahra and George, 2002; Roper et al., 2008) suggesting that some internal capacity is needed not only to permit scanning for the best available external knowledge, but to enable the efficient absorption and use of this knowledge, and to help in the appropriation of the returns from new innovations. However, perhaps reflecting the ambiguity in the theoretical literature, the empirical evidence is mixed, with some authors finding a complementary relationship between internal and external R\&D, while other find a predominantly substitute relationship (Arora and Gambardella, 1990, 1994; Veugelers and Cassiman, 1999; Love and Roper, 1999, 2001, 2002; Cassiman and Veugelers, 2006).

One other possibility is that patterns of complementarity between internal and external knowledge sources may also depend on the type of innovation being undertaken. Here, the UK and Germany provide an interesting contrast in this respect because of differences in the nature of innovation activity in the two countries (Finegold and Wagner, 1998; Herrigel, 1996), and because of the marked institutional and organizational contrasts between the two countries $^{3}$. The German innovation and production system, for example, has been characterised as having a focus on diversified quality production (DQP), involving the incremental customisation of products rather than mass production or products derived from radical innovation (Streeck, 1989). By contrast, the UK innovation and production system has been characterised by its dependency on fickle capital markets, short-term business objectives and a more opportunistic (or entrepreneurial) approach to innovation (Roper, 1997; Dore et al., 1999). The consequence is a tendency towards more radical and sporadic innovation activity in the UK and a greater disparity in performance between leading edge and less well performing businesses.

In a study of innovation organization between the two countries, Love and Roper (2004) find that these institutional and social norms do have an effect on the overall pattern of external networking in the innovation process. German plants were significantly more likely than their UK counterparts to have external linkages in each aspect of innovation activity, and there were marked differences in the reasons given for inter-plant collaboration

\footnotetext{
${ }^{3}$ A detailed analysis of the institutional and structural differences between the organization of innovation in the two countries is provided in Love and Roper (2004), and so only an overview is provided here.
} 
or co-operation between the two countries. UK manufacturing plants emphasised increased speed to market as a key reason for external networking while German plants tended to emphasise the benefits of collaboration or co-operation in terms of risk and cost sharing. This was also reflected in the contractual basis for the extra-group collaborative relationships adopted in the two countries: German plants were heavily involved in collaborative mechanisms with other firms, especially in the early stages of the innovation process, with a very limited use of formal sub-contract relationships; British plants also generally showed some preference for quasi-hierarchical, collaborative arrangements over sub-contracting, although this difference was much less marked than that for the German sample. However, in the early, more risky activities within the innovation process (e.g. identifying new products and prototyping), German plants were more likely to be working with independent partners in a relationship characterised by collaboration or trust; UK plants on the other hand were more likely to be working with other plants within their group and to have a sub-contract or legal aspect to the relationship. This evidence is consistent with that of Lane (1997) who argues that although German systems of rule-setting and regulation are highly formalised, this does not supersede more informal trust-based relationships. German manufacturing companies, it is argued, develop longer-term and closer relationships with their suppliers and customers than their British counterparts, which in turn encourages technological collaboration. By contrast, the British system of relations between firms does not encourage such behaviour.

The question posed in the comparative element of this paper is whether these differences in external networking shape the extent and pattern of complementarity between networking in the different stages of the innovation process. Milgrom and Roberts $(1990,1995)$ developed the formal analysis of complementarities in organizational design, building on the work of Topkis $(1978,1998)$, and we follow here the operationalised version of this methodological approach based on recently developed tests for complementarity in situations where strategic decision variables are discrete (Mohnen and Röller, 2005).

\section{Data and Empirical Method}

The data we use here are taken from the Product Development Survey (PDS), a nationally representative postal survey of UK and German manufacturing plants' innovation activity 
(Roper et al., 1996; Love and Roper, 2004). In each country the sample was structured to allow size-band, regional and industry sector comparisons. Overall response rates were 20.6 per cent in the UK (1722 responses) and 25.1 per cent in Germany (1374 responses). The PDS relates to plants' innovation activity during the 1991 to 1993 period, at the beginning of the German recession of the mid-1990s, and a time when the UK economy was also experiencing a mild recession (Roper et al., 1996, pp 8-9) ${ }^{4}$. The PDS is particularly well suited to examining complementarities between external knowledge sources because it provides detailed information both on firms' innovation outputs as well as the organization of firms' innovation activity (see, for example, Love and Roper, 2004).

Specifically, for innovating plants, the PDS reports the involvement of responding plants in external innovation networks in four different stages of the product innovation process: identifying new products, product design and development, product engineering, and product marketing ${ }^{5}$. This allows us to define four dichotomous strategy choice variables relating to firms' external networking in each of these stages of the product innovation process: external networking is said to exist where there is some collaborative or subcontracting innovation link outside the plant (or group of which the plant is part) in a specific element of the innovation process. Our key interest, however, is whether firms' choices in respect of external networking influence innovation output. To test this we use an innovation production function (e.g. Griliches, 1979; Love and Roper, 2001) which relates the percentage of sales derived from innovative products to a set of plant specific, industry and regional control variables along with the four strategy choice variables.

More formally, let $Z=\left(z_{1}, \ldots z_{i}, \ldots z_{n}\right)$ be the vector of $n$ exogenous plant, industry and regional control variables, and $\mathrm{M}$ be the set of four dichotomous, strategy choice variables

\footnotetext{
${ }^{4}$ Fieldwork for this study pre-dates that reported in Finegold and Wagner (1998) by 18-24 months. The intervening period was one of continuing weakness in the German economy with total employment falling by 10 per cent between 1989 and 1995 (Finegold and Wagner, 1998, p. 473)

${ }^{5}$ The PDS actually identifies external networking in seven activities in the product innovation process. For some of these activities, however, the profile of networking was very similar (e.g. Love and Roper, 2004). For the current analysis, therefore, the original seven activities were grouped into four broader categories using cluster analysis. Specifically, 'prototyping' and 'final product development' were combined into 'product design and development'; 'product testing' and 'production engineering' were combined into 'product engineering'; and, 'market research' and 'sales strategy development' were grouped into 'product marketing'. The original activity 'identifying new products' was retained. Details of the cluster analysis are available from the authors.
} 
reflecting external networking in the different stages of the innovation process. Then the innovation production function can be written:

$$
I(M, Z)=f\left(m_{1}, m_{2}, m_{3}, m_{4}, z_{1}, \ldots z_{n}\right)
$$

Then to test for complementarities between the strategy choice variables the estimated form of the innovation production function is analysed directly to test for supermodularity or submodularity with respect to the $m_{j}{ }^{6}$

By way of illustration, consider a situation where there are only two strategy choice variables $m_{1}$ and $m_{2}$, such that the vectors (00), (01), (10) and (11) define all possible combinations of strategy options. Complementarity between the two strategy choices, or here the equivalent notion of supermodularity, in the innovation production function then requires that:

$$
I(10, Z)+I(01, Z) \leq I(00, Z)+I(11, Z)
$$

In other words, complementarity or supermodularity requires positive synergy between the two strategy choices, i.e. adopting both strategy choices together produces more positive effects on innovation outputs than the sum of the results produced by each strategy choice individually. Equivalently, equation (2) can be expressed as:

$$
I(10, Z)-I(00, Z) \leq I(11, Z)-I(01, Z) .
$$

Thus, complementarity or supermodularity requires that each strategy choice has a more positive effect on innovation outputs when the other strategy choice is also adopted.

With four strategy choice variables, such as those relating to external networking considered here, the situation is more complex with each pairing of strategy choices either exhibiting complementarity or substitutability. Supermodularity is then said to exist where

\footnotetext{
${ }^{6}$ Athey and Stern (1998) provide a detailed overview of this approach to assessing complementarity and a range of other possible approaches.
} 
there is complementarity between all possible pairings of strategy choices.

Complementarity between the first two strategy choice variables requires that:

$$
I(10 X X, Z)+I(01 X X, Z) \leq I(00 X X, Z)+I(11 X X, Z),
$$

where $X X=\{00,01,10,11\}$. This generates a set of four inequality constraints, one for each value of the set $X X .^{7}$ For example, complementarity between external networking in the first (identification) and third (product engineering) stages of the innovation process requires that the following four inequalities hold:

$$
I(1 X 0 X, Z)+I(0 X 1 X, Z) \leq I(0 X 0 X, Z)+I(1 X 1 X, Z) .
$$

The set of inequalities for the remaining combinations of strategy choice variables can be derived as an analogous procedure.

In operational terms, the key result is due to Topkis (1978), that pairwise complementarity over any subset implies supermodularity within that subset. This allows us to test for supermodularity for the set of four strategic choice variables using a set of six pairwise tests for complementarity, each independent pairwise test considering the validity of four simultaneous inequality constraints (e.g. equation (5)). Operationalising these hypothesis tests requires the inclusion in the innovation production function of mutually exclusive state dummies for the 16 possible combinations of the strategic choice variables. Conventionally, we label these state dummies $(0000),(0001), \ldots,(1111)$ following the rules of binary algebra. The state dummy labelled (0000), for example, indicates no external networking, while (0001) indicates external networking only in the fourth element of the product innovation process - product marketing. (1111) indicates external networking in each of the four stages of the innovation process.

The innovation production function we estimated can therefore be written as:

$$
I_{i}=\sum_{l=0}^{15} \gamma_{l} s_{l}+\beta Z_{i}+\varepsilon_{i}
$$

\footnotetext{
${ }^{7}$ Here we use the same notation as Mohnen and Röller (2005).
} 
$I_{i}$ is an innovation output indicator, defined as the percentage of firm i's sales derived from innovative products (i.e. those products improved or newly introduced over the previous three years). This measure has been widely used in other academic studies to reflect the commercial outcomes of firms' innovation activity (Brouwer and Kleinknecht, 1996; Youtie et al., 2005) as well as a strategic benchmark to measure firms' success in renewing their product range (Davila et al., 2005). The $s_{l}$ represent the set of 16 state variables, and $Z$ is the set of plant level, industry and regional controls. Although the stages of vector $\mathrm{Z}$ are principally designed to control for plant-level heterogeneity, they are also variables which have previously been shown to be relevant determinants of innovative activity at the plant level (Love and Roper, 1999, 2001), including plant size, the intensity of internal knowledge sources (i.e. R\&D), access to group resources, workforce qualifications, and the principal form of production in the plant. We also include measures of cross-functional teamworking in each of the four stages of innovation, which previous research has shown to be positively linked to innovation (Cooper and Kleinschmidt, 1995; Zeller, 2002).

Descriptives and variable definitions are given in the Annex. Since the dependent variable measures the percentage of plants' sales due to innovative products, it can only take values between 0 and 100. The nature of the dependent variable suggests that consistent estimates for the parameters of interest can be obtained by the estimation method proposed by Papke and Wooldridge (1996) for regression models with fractional response variables. ${ }^{8}$

As noted inter alia by Athey and Stern (1998), an empirical issue in estimation of this form is that unobserved heterogeneity between observations in the sample of plants can cause bias in the estimation results, which can lead to either Type I or Type II errors in testing the null hypothesis of no complementarity. This can occur if heterogeneity in the determinants of the choice of external networking strategy is correlated with the error term of equation (6). Several methods of overcoming this potential difficulty have been mooted. The method preferred by Athey and Stern (1998) is to jointly estimate both the choice of organizational form (i.e. external networking in our case) and the innovation production function in a simultaneous system. More pragmatically, other cross-sectional studies have tried some form of instrumental variables approach to deal with the endogeneity issue (e.g.

\footnotetext{
${ }^{8}$ See Wagner (2001) for a discussion of the econometric issues arising in the estimation of model with fractional response variable applied to the export/sales ratio.
} 
Mohnen and Röller, 2005; Cassiman and Veugelers, 2006). However, these approaches have generally proved unsuccessful because of the difficulty of obtaining suitable instruments within highly specific microeconomic datasets in which the observations cannot be merged with other datasets which might provide suitable instruments for e.g. variations in managerial expertise. This has led both Mohnen and Röller (2005) and Cassiman and Veugelers (2006) to the conclusion that attempts at instrumentation, or even joint estimation as suggested by Athey and Stern (1998), are unlikely to lead to improved estimation and may actually be counterproductive unless much better - i.e. truly exogenous - instruments can be found ${ }^{9}$. Our data share many of the characteristics of the other cross-sectional studies referred to, including a lack of reliable instruments for the choice of external networking strategy. Rather than adopt an empirical method which we know from previous studies is unlikely to resolve the issue of endogeneity therefore, we have avoided the use of instrumentation in our estimation. We nevertheless acknowledge the potential for endogeneity and recognize that our results must be interpreted in this light.

\section{Empirical Results}

Innovation production functions for the UK and Germany using fractional response are reported in Table 1. In each case, observations are weighted to provide nationally representative results (see Roper et al., 1996), and both models include industry dummies (not reported). Wald tests of joint significance are reported for the state dummies, networking, size and other control variables. For both countries, the $\chi^{2}$ statistics suggest a high level of joint statistical significance for all sets of variables. Table 2 reports the marginal effects for the state dummies and for the main control variables for each country. ${ }^{10}$

The coefficients of the individual external networking dummies do not by themselves provide any information on complementarity between different combinations of external

\footnotetext{
${ }^{9}$ In the case of panel data analysis, Leiponen (2005) deals with this issue by assuming that unobserved heterogeneity does not change over time, so that the GMM systems estimation controls for unobserved firm fixed effects. Miravete and Pernías (2006) attempt an econometric model which separately identifies the unobserved heterogeneity in their panel of Spanish ceramics firms. However, they admit that many of the regressors used in their estimation are actually themselves endogenous and that they too lack suitable instruments (p 19 footnote 9).

${ }^{10}$ The estimated model includes a constant term, which is also retained in calculating the associated marginal effects. The omitted category for the state dummies is 0000 to allow comparison with the situation where no multifunctional teams are present. However, for the purpose of the complementarity test, the model is estimated without a constant as implied by Equation 6 .
} 
networking. Instead, as equation (5) implies testing for complementarity involves testing a set of linear inequality restrictions, and indeed testing the joint distribution of several of these restrictions (Mohnen and Röller, 2005; Leiponen, 2005) ${ }^{11}$. Nevertheless, the individual state dummies do give an indication of the effects of different combinations of external networking on innovation output. For the UK the most positive combinations of external networking involve using external knowledge in identifying new products with either product design and development, product engineering, or product marketing respectively (i.e. combinations 1001, 1010, 1100). Each of these individually raises innovation output by around 15 per cent (Table 2). However, this effect is restricted to simple combinations involving the first element (identifying new products) and one of the others; involving external networks for the final three elements (0111) or all four (1111) reduces innovation output by 10 and 7.4 per cent respectively, suggesting that external networking combinations in the later stages of the innovation process has a detrimental effect on innovation for UK firms. For Germany, only one combination of external networking (1110) has an effect which is individually significant, reducing innovation output by 6.2 per cent (Table 2).

As indicated earlier, assessing complementarity or substitutability between cross-functional teamworking in different stages of the innovation process requires the joint testing of four inequality constraints for each pairwise comparison. Following Mohnen and Röller (2005), Table 3 reports the relevant Wald tests of the inequality restrictions (i.e. equation 5) based on the coefficient estimates on the state variables in the fractional response models from Table 1. In each pairwise comparison, separate tests are required for the null hypotheses of complementarity and substitutability. Test values below the lower bound suggest that the null hypothesis of complementarity or substitutability cannot be rejected; values above the upper bound suggest rejection of the null; and, intermediate values suggest indeterminacy. Critical values at a 10 per cent significance level are 1.642 and 7.094 (see Kodde and Palm, 1986). For the UK, for example, the test for complementarity between external networking in identifying new products and product design and development (i.e. combinations 1 and 2) is unable to reject the null hypothesis, while the test for substitutability is indeterminate. For this pairing the tests therefore suggest complementarity. Test results are summarised in

\footnotetext{
${ }^{11}$ For this reason the significance or otherwise of any or all of the individual dummies' coefficients is irrelevant in deciding whether the joint hypothesis of supermodularity is accepted or rejected.
} 
symbolic form in Table 4 . In all but one case ${ }^{12}$ the test results give an unambiguous indication of either complementarity or substitutability, and in several cases acceptance of one is accompanied by rejection of the other (signified by an asterisk in Table 4).

Our test results suggest no overall evidence of either supermodularity or submodularity in external knowledge sourcing in either the UK or Germany (Table 4). That is, there is no universal pattern of complementarity or substitutability between innovation networking in the product innovation process. Instead, in both countries there is a more complex picture. The results for the UK are particularly striking, with very strong evidence of substitutability in most stages of the innovation process. Tables 3 and 4 indicate that there is substitutability between the second and third, third and fourth and second and fourth stages of the innovation process, which in turn indicates joint substitutability between all three stages. By contrast, there is a complementary relationship between identifying new products and product design and development. Thus positive synergies between external networking are limited to the earliest stages of the innovation process; any combination of external knowledge sourcing beyond the earliest stages actually reduces the benefits of such networking in any individual stage, a result in keeping with the individual effects noted in Tables 1 and 2. In general, therefore, for UK manufacturers, the use of combinations of external networking in different stages of the innovation process actually reduces rather than enhances the innovation 'payoff' from accessing external knowledge sources.

The results for Germany shows some similarities with those for the UK, most notably in the substitutability between external networking in product engineering and all other stages of the innovation process i.e. the benefits of external networking in any other stage is reduced if there is also external networking in the product engineering phase. However, there is also more evidence of complementarity in the German case. As with the UK, complementarity exists between networking in the two earliest stages of innovation, but there is also evidence of synergy between product marketing and both identification of new products and product design and development, and of joint complementarity among these three elements of the process. For German manufacturers, therefore, the key to the optimal use of external networks is to employ them in combination except in the product engineering stage. This is

\footnotetext{
${ }^{12}$ This case is new product identification and product marketing in the UK, where neither the hypothesis of complementarity nor that of substitutability can be rejected (Table 3 ).
} 
the most technical, engineering-led phase of the innovation process, and the one in which German manufacturers are generally regarded as having the strongest skill set and where external knowledge may have least to offer (Herrigel, 1996; Soskice, 1997). Product engineering is also the element of the innovation process stage in which German plants are least likely to use external networking (Love and Roper, 2004), suggesting an appreciation of the strategic use of external networks in the appropriate combination.

\section{Conclusions and Implications for Management}

A number of studies have advocated the combination of internal and external knowledge sources as a key element of a successful innovation strategy (e.g. Arora and Gambardella, 1990, 1994; Veugelers and Cassiman, 1999; Cassiman and Veugelers, 2006). Our focus in this paper has been to assess the benefits of external networking for innovation, and explore complementarities between such networking in different stages of the innovation process. To our knowledge, this has not previously been attempted. While our results do not directly cast doubt on the findings of these earlier studies, they do suggest that studies indicating strong complementarity between internal and external knowledge sources have provided only part of the picture of the strategic dilemmas facing firms.

The purpose of the present study is therefore to go beyond considering the possible benefits of using internal and external knowledge overall in the innovation process, and to examine two related issues. First, at which stages of the process are knowledge complementarities most in evidence? Second, what is the extent of complementarity across different stages of the innovation process? As indicated in the introduction, we cannot merely consider the complementarity between internal and external knowledge in each individual stage, because of the potential for complementarities in the use of internal and external knowledge between stages.

We find some evidence, both in the UK and Germany, suggesting synergies in the implementation of external networking, notably in the earlier stages of the innovation process. However, other combinations of external networking prove less positive for innovation, suggesting that external networking is not a universal good, and implemented in the wrong phase of the innovation process can actually have a negative impact on 
innovation output. Moreover, we also find no evidence for supermodularity in relation to external networking in our innovation production functions for either the UK or Germany. In other words, complementarity between external networking in different stages of the innovation process cannot be assumed. Instead, in some activities, external networking has a negative effect on the benefits of external networking implemented elsewhere, particularly in the UK.

Our evidence also suggests some differences between the UK and Germany in terms of the optimal combination of innovation activities in which to implement external networking. Broadly, there is more evidence of complementarities in the case of Germany, with the exception of the product engineering phase. By contrast, the UK exhibits generally strong evidence of substitutability in external networking in different stages, except between the identification of new products and product design and development. It seems likely that this pattern is linked not only to differences in the extent of external networking employed by UK and German plants, but also to the differences in the rationale for external engagement outlined earlier. As detailed in Love and Roper (2004), UK plants adopt a highly pragmatic attitude to collaboration and networking with outside knowledge sources, based on considerations such as speed to market, with little emphasis on long-term development issues. By contrast, German plants generally put more emphasis on risk-sharing and cost issues and show more inclination to concern themselves with the sharing of technical knowledge between network partners. This rather less utilitarian approach to external involvement in Germany is reflected in a pattern of networking which favours complementarity - with the single exception of the product engineering phase - while substitutability is the general finding in the UK.

Implications for management are threefold. First, complementarities in the use of external knowledge across all stages of the innovation process are difficult to develop. In neither country is there is a universal pattern of complementarity (or indeed of substitutability) between innovation networking in the product innovation process. Instead, there is a more complex picture, suggesting that the use of external networking is a strategic choice for each company. Second, where complementarities in external networking between different stages are found, these tend to be in the early stages of the innovation process; notably these occur between the identification and product design and development stages in both 
countries. Third, the optimal pattern of external networking appears to be linked both to the available skill sets within the firm, and to the rationale for external networking. As indicated in the discussion above regarding engineering skills in Germany, external networking in stages of conspicuously strong internal skills is unlikely to be complementary with internal networking in other stages. More speculatively, an emphasis on short-term development issues rather than risk- and knowledge-sharing appears less likely to result in complementarities in external networking across different stages of innovation.

The finding that, in general terms, complementarities are most evident in the early stages of the innovation process may have relevance for the debate on open innovation. It is at the early, more exploratory stage, of the innovation process that 'openness' may be more beneficial, particularly where this is combined with internal knowledge generation (Laursen and Salter 2006). This suggests something of a re-thinking of the traditional notion of the product development funnel, with implications for the organization of innovation projects. In particular, our results suggest that the product development funnel should not simply be defined in terms of the range of ideas originally considered, but also their source. During the early stages of the product development process our results suggest it is likely to be optimal to consider many ideas from diverse sources. Later in the process, optimality requires a more focused approach and the internalization of the product development process. There is an analogy here with the requirements for a successful mountaineering expedition. During the early stages of a climb the skills and efforts of many people are involved to develop the project plan, assemble the resources for the climb and eventually to establish the base camp. As higher and higher camps are then established fewer climbers are involved until the final success of the expedition depends crucially on the team who make the final push for the summit.

Our empirical results for UK and German firms therefore provide some new insights into the potential sources of complementarities in the organization of firms' innovation activities. Roper et al., (2008), however, provide evidence of further international differences in firms' learning capabilities, and their ability to benefit from such complementarities. The implication is that considerable work remains to be done in teasing out the extent to which combinations of internal and external knowledge are optimal in different types of innovation projects and in different operating contexts. In particular, 
further comparative work which seeks to compare patterns of complementarity across different countries would be welcome, as would research on different types of innovation (i.e. product versus process) as well as the different stages of the product development process. Above all, we now have evidence that a 'one-size-fits-all' strategy with regard to external knowledge sourcing is unlikely to be optimal with respect to the innovation process. 
Table 1: New products as a percentage of sales - Fractional response model

\begin{tabular}{|c|c|c|c|c|}
\hline & \multicolumn{2}{|c|}{ United Kingdom } & \multicolumn{2}{|c|}{ Germany } \\
\hline Wald test of overall significance & $\begin{array}{c}\operatorname{chi} 2(36)= \\
150.91\end{array}$ & $(0.000)$ & $\begin{array}{c}\operatorname{chi} 2(37)= \\
244.87\end{array}$ & $(0.000)$ \\
\hline 0001 & 0.88264 & $(0.003) * * *$ & 0.31332 & $(0.341)$ \\
\hline 0010 & 0.49846 & $(0.068)^{*}$ & 0.40802 & $(0.135)$ \\
\hline 0011 & -0.29340 & $(0.306)$ & 0.14577 & $(0.451)$ \\
\hline 0100 & -0.24412 & $(0.518)$ & -0.24127 & $(0.283)$ \\
\hline 0101 & -0.25806 & $(0.432)$ & 0.02707 & $(0.918)$ \\
\hline 0110 & 0.09961 & $(0.760)$ & 0.18533 & $(0.530)$ \\
\hline 0111 & -0.74869 & $(0.014)^{* *}$ & -0.03097 & $(0.926)$ \\
\hline 1000 & 0.11926 & $(0.753)$ & -0.32108 & $(0.328)$ \\
\hline 1001 & 0.75654 & $(0.018) * *$ & 0.19770 & $(0.545)$ \\
\hline 1010 & 0.74113 & $(0.046) * *$ & 0.30868 & $(0.259)$ \\
\hline 1011 & 0.26432 & $(0.473)$ & -0.18017 & $(0.598)$ \\
\hline 1100 & 0.82172 & $(0.003)^{* * *}$ & 0.18699 & $(0.550)$ \\
\hline 1101 & 0.62261 & $(0.366)$ & 0.12256 & $(0.542)$ \\
\hline 1110 & -0.20356 & $(0.526)$ & -0.49417 & $(0.014)^{* *}$ \\
\hline 1111 & -0.50701 & $(0.013) * *$ & 0.35061 & $(0.634)$ \\
\hline All state dummies $(0001-1111)$ & $\begin{array}{c}\operatorname{chi2}(15)= \\
56.52\end{array}$ & $(0.000)$ & $\begin{array}{c}\operatorname{chi} 2(15)= \\
20.36\end{array}$ & $(0.158)$ \\
\hline R\&D intensity (\% of employment) & 0.01789 & $(0.125)$ & 0.01766 & $(0.000)^{* * *}$ \\
\hline CFT - Identifying new products & 0.08325 & $(0.213)$ & 0.11916 & $(0.287)$ \\
\hline $\begin{array}{l}\text { CFT - Product design and } \\
\text { development }\end{array}$ & 0.08351 & $(0.338)$ & 0.12033 & $(0.189)$ \\
\hline CFT - Product engineering & -0.26229 & $(0.005)^{* * *}$ & 0.02022 & $(0.854)$ \\
\hline CFT - Product marketing & 0.12998 & $(0.091)^{*}$ & -0.06742 & $(0.617)$ \\
\hline $\begin{array}{l}\text { All Cross Functional Teamworking } \\
\text { (Wald Test) }\end{array}$ & $\begin{array}{c}\operatorname{chi} 2(4)= \\
10.08\end{array}$ & $(0.039)$ & $\operatorname{chi} 2(4)=8.71$ & $(0.069)$ \\
\hline Employment (Thousands) & 0.24744 & $(0.347)$ & -0.02323 & $(0.920)$ \\
\hline Employment squared & -0.02343 & $(0.167)$ & 0.03342 & $(0.480)$ \\
\hline $\begin{array}{l}\text { Employment and Employment } \\
\text { squared (Wald Test) }\end{array}$ & $\begin{array}{c}\operatorname{chi} 2(2)= \\
12.20\end{array}$ & $(0.002)$ & $\operatorname{chi} 2(2)=2.39$ & $(0.302)$ \\
\hline Part of group & 0.05143 & $(0.734)$ & -0.33761 & $(0.030)^{* *}$ \\
\hline External ownership dummy & -0.18154 & $(0.282)$ & 0.86741 & $(0.023)^{* *}$ \\
\hline $\begin{array}{l}\text { Part of group and external } \\
\text { ownership }\end{array}$ & $\operatorname{chi} 2(2)=1.18$ & $(0.555)$ & $\operatorname{chi} 2(2)=8.20$ & $(0.017)$ \\
\hline Workforce with degrees (per cent) & 0.00931 & $(0.237)$ & 0.01364 & $(0.212)$ \\
\hline $\begin{array}{l}\text { Workforce with no qualifications } \\
\text { (per cent) }\end{array}$ & -0.00017 & $(0.952)$ & -0.00423 & $(0.227)$ \\
\hline Degree and No qualifications & $\operatorname{chi} 2(2)=1.47$ & $(0.480)$ & $\operatorname{chi} 2(2)=4.22$ & $(0.1212)$ \\
\hline Small batch production & -0.20044 & $(0.197)$ & -0.17418 & $(0.330)$ \\
\hline Large batch production & -0.11910 & $(0.420)$ & -0.11068 & $(0.541)$ \\
\hline One-off production & -0.47578 & $(0.014)^{* *}$ & -0.17390 & $(0.299)$ \\
\hline Continuous production & 0.08481 & $(0.616)$ & 0.04997 & $(0.781)$ \\
\hline All production types & $\begin{array}{c}\operatorname{chi} 2(4)= \\
10.64\end{array}$ & $(0.031)$ & $\operatorname{chi} 2(4)=3.18$ & $(0.529)$ \\
\hline Textiles and clothing & 0.65027 & $(0.067)^{*}$ & 0.40741 & $(0.216)$ \\
\hline Metals and metal fabrication & -0.30128 & $(0.399)$ & -0.09502 & $(0.750)$ \\
\hline Mechanical engineering & 0.24462 & $(0.431)$ & 0.08722 & $(0.801)$ \\
\hline Electrical and optical equipment & 0.51615 & $(0.139)$ & 0.26207 & $(0.393)$ \\
\hline Transport equipment & 1.12423 & $(0.002)^{* * *}$ & -0.12579 & $(0.721)$ \\
\hline Other manufacturing & 0.09376 & $(0.768)$ & 0.06467 & $(0.829)$ \\
\hline Industry dummies (Wald test) & $\begin{array}{c}\operatorname{chi2}(6)= \\
27.33\end{array}$ & $(0.000)$ & $\operatorname{chi} 2(6)=6.30$ & $(0.390)$ \\
\hline Former East Germany & NA & & 1.25482 & $(0.000)^{* * *}$ \\
\hline Constant & -1.58203 & $(0.000)^{* * *}$ & -1.97834 & $(0.000)^{* * *}$ \\
\hline
\end{tabular}


Notes: Models relate to manufacturing plants with 20 or more employees. Estimates are weighted using employment based weights to ensure representativeness of the UK and Germany. A Wald test of joint significance is reported for groups of variables such as state dummies, multifunctional team working etc. The estimated model includes a constant term, which is also retained in calculating the associated marginal effects. The omitted category for the state dummies is 0000 to allow comparison with the situation where no multifunctional teams are present. However, for the purpose of the complementarity test, the model is estimated without a constant as implied by Equation 1. Robust $\mathrm{p}$ values in parentheses: * significant at $10 \%$; $* *$ significant at $5 \%$; *** significant at $1 \%$. CFT $=$ cross-functional team-working. 
Table 2: Marginal effects from Fractional Response Models

UK

\begin{tabular}{|c|c|c|c|c|c|c|}
\hline Variable & $d y / d x$ & Std. Er. & $\mathrm{z}$ & $d y / d x$ & Std. Er. & $\mathrm{z}$ \\
\hline $0001 *$ & 0.184 & 0.070 & 2.640 & 0.051 & 0.057 & 0.890 \\
\hline $0010 *$ & 0.096 & 0.057 & 1.690 & 0.068 & 0.050 & 1.370 \\
\hline $0011 *$ & -0.046 & 0.042 & -1.090 & 0.022 & 0.030 & 0.740 \\
\hline $0100^{*}$ & -0.038 & 0.056 & -0.690 & -0.033 & 0.029 & -1.120 \\
\hline $0101^{*}$ & -0.040 & 0.048 & -0.840 & 0.004 & 0.039 & 0.100 \\
\hline $0110 *$ & 0.017 & 0.058 & 0.300 & 0.029 & 0.048 & 0.600 \\
\hline $0111^{*}$ & -0.101 & 0.034 & -2.970 & -0.005 & 0.048 & -0.090 \\
\hline $1000 *$ & 0.021 & 0.068 & 0.310 & -0.043 & 0.040 & -1.070 \\
\hline $1001^{*}$ & 0.154 & 0.073 & 2.110 & 0.031 & 0.053 & 0.580 \\
\hline $1010 *$ & 0.150 & 0.085 & 1.770 & 0.050 & 0.047 & 1.060 \\
\hline $1011^{*}$ & 0.048 & 0.071 & 0.680 & -0.025 & 0.045 & -0.550 \\
\hline $1100 *$ & 0.169 & 0.065 & 2.600 & 0.029 & 0.051 & 0.570 \\
\hline $1101 *$ & 0.123 & 0.154 & 0.800 & 0.019 & 0.031 & 0.600 \\
\hline $1110^{*}$ & -0.032 & 0.049 & -0.670 & -0.062 & 0.024 & -2.620 \\
\hline $1111^{*}$ & -0.074 & 0.027 & -2.700 & 0.058 & 0.133 & 0.430 \\
\hline $\mathrm{R} \& \mathrm{D}$ intensity (\% of employment) & 0.003 & 0.002 & 1.540 & 0.003 & 0.001 & 3.590 \\
\hline CFT - Identifying new products* & 0.015 & 0.012 & 1.240 & 0.018 & 0.017 & 1.070 \\
\hline $\begin{array}{l}\text { CFT - Product design and } \\
\text { development } *\end{array}$ & 0.015 & 0.016 & 0.950 & 0.018 & 0.014 & 1.310 \\
\hline CFT - Product engineering * & -0.047 & 0.017 & -2.740 & 0.003 & 0.017 & 0.180 \\
\hline CFT - Product marketing * & 0.023 & 0.014 & 1.690 & -0.010 & 0.020 & -0.500 \\
\hline Employment (Thousands) & 0.044 & 0.047 & 0.940 & -0.003 & 0.035 & -0.100 \\
\hline Employment squared & -0.004 & 0.003 & -1.380 & 0.005 & 0.007 & 0.700 \\
\hline Part of group * & 0.009 & 0.027 & 0.340 & -0.047 & 0.020 & -2.310 \\
\hline External ownership dummy * & -0.031 & 0.028 & -1.120 & 0.164 & 0.086 & 1.920 \\
\hline Workforce with degrees (per cent) & 0.002 & 0.001 & 1.190 & 0.002 & 0.002 & 1.250 \\
\hline $\begin{array}{l}\text { Workforce with no qualifications } \\
\text { (per cent) }\end{array}$ & 0.000 & 0.001 & -0.060 & -0.001 & 0.001 & -1.200 \\
\hline Small batch production $*$ & -0.036 & 0.028 & -1.280 & -0.026 & 0.027 & -0.970 \\
\hline Large batch production * & -0.021 & 0.026 & -0.810 & -0.016 & 0.026 & -0.620 \\
\hline One-off production * & -0.078 & 0.029 & -2.670 & -0.026 & 0.024 & -1.070 \\
\hline Continuous production * & 0.015 & 0.031 & 0.500 & 0.008 & 0.027 & 0.280 \\
\hline Former East Germany * & & & & 0.246 & 0.042 & 5.870 \\
\hline
\end{tabular}

Notes: * denotes marginal effect is for discrete change of dummy variable from 0 to 1 . Marginal effects for each state dummy are calculated setting all other state dummies at zero and all other variables at their mean values. Marginal effects for variables other than state dummies are calculated setting all variables at their mean value. $\mathrm{CFT}=$ cross-functional team-working. 
Table 3. Wald Test Results for Complementarity and Substitutability in External Networking

\begin{tabular}{|c|c|c|c|c|c|c|}
\hline $\begin{array}{c}\text { Combinations of networking } \\
\text { activities }\end{array}$ & $1-2$ & $1-3$ & $1-4$ & $2-3$ & $2-4$ & $3-4$ \\
\hline A. UK & & & & & & \\
\hline Supermodularity Test & 1.048 & 5.242 & 0.228 & 7.431 & 3.459 & 19.894 \\
\hline Submodularity Test & 3.660 & 1.347 & 1.237 & 1.345 & 0.088 & 0.000 \\
\hline B. Germany & & & & & & \\
\hline & & & & & & \\
\hline Supermodularity Test & & & & & & \\
\hline Submodularity Test & 1.282 & 5.023 & 0.712 & 5.807 & 1.207 & 5.360 \\
\hline
\end{tabular}

Notes: Networking activities definitions: 1: Identifying new products; 2: Product design and development; 3: Product engineering; 4: Product marketing. Wald test of inequality restrictions based on fractional response model. Critical values for $\alpha=0.10$ are 1.642 for lower bound and 7.094 for upper bound. See Kodde and Palm (1986). If the Wald statistic is below the lower bound, the null hypothesis of supermodularity or submodularity cannot be rejected. If the Wald statistic is above the upper bound, the null hypothesis is rejected. The test is inconclusive for intermediate values. 
Table 4: Summary of Patterns of Complementarity and Substitutability in External Networking

\begin{tabular}{|l|l|l|l|}
\hline \multicolumn{4}{|c|}{ UK } \\
\hline & $\begin{array}{l}\text { Identifying } \\
\text { new } \\
\text { products }\end{array}$ & $\begin{array}{l}\text { Product } \\
\text { Design and } \\
\text { Development }\end{array}$ & $\begin{array}{l}\text { Product } \\
\text { Engineering }\end{array}$ \\
\hline $\begin{array}{l}\text { Identifying } \\
\text { new products }\end{array}$ & C & & \\
\hline $\begin{array}{l}\text { Product } \\
\text { Design and } \\
\text { Development }\end{array}$ & S & $\mathrm{S}^{*}$ & \\
\hline $\begin{array}{l}\text { Product } \\
\text { Engineering }\end{array}$ & - & $\mathrm{S}$ & $\mathrm{S}^{*}$ \\
\hline $\begin{array}{l}\text { Product } \\
\text { Marketing }\end{array}$ & - & \\
\hline $\begin{array}{l}\text { C: complementarity } \\
\text { S: substitutability } \\
* \text { failure to reject the null is also accompanied by } \\
\text { rejection of the alternative }\end{array}$ \\
\hline
\end{tabular}

\begin{tabular}{|l|l|l|l|}
\hline \multicolumn{4}{|c|}{ Germany } \\
\hline & $\begin{array}{l}\text { Identifying } \\
\text { new } \\
\text { products }\end{array}$ & $\begin{array}{l}\text { Product } \\
\text { Design and } \\
\text { Development }\end{array}$ & $\begin{array}{l}\text { Product } \\
\text { Engineering }\end{array}$ \\
\hline $\begin{array}{l}\text { Identifying } \\
\text { new products }\end{array}$ & C & & \\
\hline $\begin{array}{l}\text { Product } \\
\text { Design and } \\
\text { Development }\end{array}$ & & S & \\
\hline $\begin{array}{l}\text { Product } \\
\text { Engineering }\end{array}$ & $\mathrm{S}$ & $\mathrm{S}$ & $\mathrm{S}$ \\
\hline $\begin{array}{l}\text { Product } \\
\text { Marketing }\end{array}$ & $\mathrm{C}$ & $\mathrm{C}$ & \\
\hline $\begin{array}{l}\text { C: complementarity } \\
\text { S: substitutability }\end{array}$ & & \\
\end{tabular}




\section{Annex: Data Descriptives}

\begin{tabular}{|l|r|r|r|r|}
\hline & \multicolumn{2}{|c|}{ UK } & \multicolumn{2}{c|}{ Germany } \\
\hline \multicolumn{1}{|c|}{ Variable } & Mean & \multicolumn{1}{c|}{$\begin{array}{c}\text { Standard } \\
\text { error }\end{array}$} & \multicolumn{1}{c|}{ Mean } & \multicolumn{1}{c|}{$\begin{array}{c}\text { Standard } \\
\text { error }\end{array}$} \\
\hline R\&D Intensity (\% of workforce) & 4.30 & 5.99 & 4.51 & 7.71 \\
\hline $\begin{array}{l}\text { Cross-functional teamworking (mean } \\
\text { level): }\end{array}$ & & & & \\
\hline Identifying new products & 2.61 & 1.35 & 1.71 & 0.79 \\
\hline Product design and development & 3.02 & 1.30 & 1.87 & 0.90 \\
\hline Product engineering & 2.46 & 1.28 & 1.56 & 0.66 \\
\hline Product marketing & 1.95 & 1.31 & 1.27 & 0.55 \\
\hline Employment (Thousands) & 0.13 & 0.31 & 0.24 & 0.49 \\
\hline Part of group (\%) & 0.51 & 0.50 & 0.15 & 0.36 \\
\hline Externally-owned (\%) & 0.15 & 0.36 & 0.02 & 0.13 \\
\hline Workforce with degree (\%) & 7.74 & 9.50 & 7.11 & 6.94 \\
\hline Workforce with no qualifications (\%) & 49.12 & 28.24 & 33.50 & 26.16 \\
\hline Small batch production (\%) & 0.53 & 0.50 & 0.46 & 0.50 \\
\hline Large batch production (\%) & 0.29 & 0.45 & 0.21 & 0.41 \\
\hline One-off production (\%) & 0.20 & 0.40 & 0.28 & 0.45 \\
\hline Continuous production (\%) & 0.22 & 0.41 & 0.29 & 0.46 \\
\hline Former East Germany plant (\%) & & & 0.0938 & 0.29187 \\
\hline Source: Product Development Survey & & & & \\
\hline
\end{tabular}

Source: Product Development Survey - see Roper et al. (1996). 


\section{References}

Arora, A. and Gambardella, A. (1990) 'Complementarity and external linkages: the strategies of the large firms in biotechnology', Journal of Industrial Economics, 38, 361379.

Arora, A. and Gambardella, A. (1994) 'Evaluating technological information and utilizing it: Scientific knowledge, technological capability and external linkages in biotechnology', Journal of Economic Behaviour and Organization, 24, 91-114.

Athey, S and Stern, S (1998) An Empirical Framework for Testing Theories About Complementarity in Organizational Design. NBER Working Paper 6600.

Audretsch, D B, Menkveld, A J and Thurik, A R (1996) 'The Decision Between Internal and External R\&D', Journal of Institutional and Theoretical Economics, 152, 517-30.

Brouwer, E and Kleinknecht, A (1996) 'Firm size, small business presence and sales of innovative products: a microeconomic analysis', Small Business Economics, 8, 189-201.

Cassiman, B and Veugelers, R (2006) 'In Search of Complementarity in Innovation Strategy: Internal R\&D and External Knowledge Acquisition', Management Science, 52, 68-82.

Chesbrough, H (2003) Open Innovation, Harvard Business School Press, Harvard.

Cohen, W.M., Levinthal, D.A. (1989) 'Innovation and learning: the two faces of R\&D'. The Economic Journal, 99, 569-596.

Cooper, R G and Kleinschmidt. E. J. (1995). Benchmarking for firm's critical success factors in new product development. Journal of Product Innovation Management, 12 374391.

Culpepper, P. D. (1999), 'The future of the high-skill equilibrium in Germany', Oxford Review of Economic Policy, 15, 43-59.

Davila, T Epstein, M J and Shelton, R (2005) Making Innovation Work - How to manage it, measure it and profit from it, Wharton School Publishing.

Dore, R., Lazonick, W. and O'Sullivan, M. (1999). Varieties of capitalism in the twentieth century, Oxford Review of Economic Policy, vol 15, 102-120

Finegold, D. and Soskice, D. (1988) 'The failure of training in Britain: analysis and prescription', Oxford Review of Economic Policy, 4, 21-53.

Finegold, D. and Wagner, K. (1998) 'The search for flexibility: skills and workplace innovation in the German pump industry', British Journal of Industrial Relations, 36, 469487. 
Griffith, R Redding, S and Van Reenan, J (2003) 'R\&D and Absorptive Capacity: Theory and Empirical Evidence', Scandinavian Journal of Economics, 105, 1, 99-118.

Griliches, Z (1979) "Issues in Assessing the Contribution of Research and Development to Productivity Growth.” Bell Journal of Economics 10, 1, 92-116.

Harrison J S, Hitt M A, Hoskisson R E and Ireland R D (2001) 'Resource complementarity in business combinations: Extending the logic to organizational alliances', Journal of Management, 27, 679-690.

Herrigel, G. (1996) 'Crisis in German decentralised production', European Urban and Regional Studies, vol. 3, 33-52.

Kodde, D A. and Palm, F C (1986) 'Wald Criteria for Jointly Testing Equality and Inequality Restrictions', Econometrica, 54, 1243-1248.

Lane, C (1997) 'The social regulation of inter-firm relations in Britain and Germany: market rules, legal norms and technical standards', Cambridge Journal of Economics, vol. $21,197-215$

Laursen, K, and A Salter (2006) 'Open for Innovation: The role of openness in explaining innovation performance among UK manufacturing firms', Strategic Management Journal $27,131-150$.

Leiponen, A (2005) 'Skills and innovation', International Journal of Industrial Organization, 23, 303-323.

Love, J. H. and Roper, S. (1999) 'The determinants of innovation: R\&D, technology transfer and networking effects', Review of Industrial Organization, 15, 43-64.

Love, J. H. and Roper, S (2001) 'Location and network effects on innovation success: evidence for UK, German and Irish manufacturing plants', Research Policy, 30, 643-61.

Love J H and Roper S (2002) 'Internal versus external R\&D: a study of R\&D choice with sample selection, International Journal of the Economics of Business, 9, 239-255.

Love, J H and Roper, S (2004) 'The Organisation of Innovation: Collaboration, Cooperation and Multifunctional Groups in UK and German Manufacturing', Cambridge Journal of Economics, 28, 379-395.

Milgrom, P and Roberts, J. (1990) "The economics of modern manufacturing: technology, strategy, and organization." American Economic Review, 80, 511-528.

Milgrom, P and Roberts, J (1995)'Complementarities and fit: strategy, structure, and organizational change in manufacturing', Journal of Accounting and Economics, 19, 179208. 
Miravete E J and Pernías J C (2006) 'Innovation complementarity and scale of production', Journal of Industrial Economics, 54, 1-29.

Mohnen, P and Röller, L-H (2005) 'Complementarities in Innovation Policy', European Economic Review, 49, 1431-1450.

Mowery, D C (1990) 'The Development of Industrial Research in US Manufacturing', The American Economic Review, 80, 345-9.

Niosi J (1999) 'The Internationalization of Industrial R\&D: from Technology Transfer to the Learning Organization' Research Policy, 28, 107-17.

Papke, L E. and J M. Wooldridge (1996) 'Econometric Methods for Fractional Response Variables with an Application to 401 (K) Plan Participation Rates',. Journal of Applied Econometrics, 11, 619-632.

Porter, M (1996) 'What is Strategy? 'Harvard Business Review, 74(6), 61-78.

Prencipe, A (1997) 'Technological competencies and products' evolutionary dynamics: a case study from the aero-engine industry', Research Policy, 25, 1261-1276.

Roper, S. (1997) 'Product innovation and small business growth: a comparison of the strategies of German, UK and Irish companies', Small Business Economics, 9, 523-37

Roper. S., Ashcroft, B., Love, J. H., Dunlop, S., Hofmann, H. and Vogler-Ludwig, K (1996) Product Innovation and Development in UK, German and Irish Manufacturing, Northern Ireland Economic Research Centre/Fraser of Allander Institute, University of Strathclyde.

Roper S, Du J and Love J H (2008) 'Modelling the Innovation Value Chain', Research Policy, 37, 961-977.

Roper, S, Youtie, J Shapira, P and Fernandez-Ribas, A (2008) 'Knowledge, Capabilities and Manufacturing Innovation: A US-Europe Comparison', Regional Studies, forthcoming.

Soskice, D. (1997) German technology policy, innovation, and national institutional frameworks, Industry and Innovation, vol. 4, 75-96

Streeck, W. (1989) Skills and the limits of neo-liberalism: the enterprise of the future as a place of learning, Work, Employment and Society, vol. 3, 89-104

Takeishi A (2001) 'Bridging inter- and intra-firm boundaries: management of supplier involvement in automobile product development', Strategic Management Journal, 22, 403-33.

Topkis, D M (1998) Supermodularity and complementarity, Princeton University Press, Princeton NJ.

Topkis, D M. (1978) 'Minimizing a Submodular Function on a Lattice', Operations Research, 26, 305-321. 
Ulset, S (1996) 'R\&D Outsourcing and Contractual Governance: and Empirical Study of Commercial R\&D Projects', Journal of Economic Behaviour and Organization, 30, 63-82.

Wagner, J. (2001). 'A Note on the firm size-export relationship', Small Business Economics, 17, 229-237.

Veugelers, R. and Cassiman, B. (1999) 'Make and buy in innovation strategies: evidence from Belgian manufacturing firms', Research Policy, vol. 28, 63-80.

Youtie, J Shapira, P Slanina, J Wang, J and Zhang, J (2005) 'Innovation in Manufacturing: Needs, Practices, and Performance in Georgia, 2002-2005', GaMEP Evaluation Working Paper E200502, Georgia Institute of Technology, Atlanta.

Zahra S A and George G (2002) 'Absorptive capacity: a review, re-conceptualization, and extension', Academy of Management Review, 27, 185-203.

Zeller, C (2002) 'Project teams as means of restructuring research and development in the pharmaceutical industry', Regional Studies, 36, 275-289. 